\title{
ACCELERATED DRYING AND STABILIZATION OF CANOLA SEEDS AND OIL.
}

\author{
Gamea, G.R. ${ }^{1}$, Taha, A.T. ${ }^{2}$, EL-kholy, M.M. ${ }^{3}$ and Wehaish, H. I. ${ }^{4}$
}

\section{ABESTRACT}

A study was carried out to evaluate the effect of accelerated drying on seeds moisture content and stabilization the extracted oil using a conduction heating rotary dryer. the drying temperatures were set at approximately $\left(85,95,105,115,125,135\right.$, and $\left.145^{\circ} \mathrm{c}\right)$ and the drying times were set at $(3,6,9,12,15$, and18 $\mathrm{min})$ and the moisture contents of canola seeds was (21\%-27\%-31\%). The results showed that all the drying processes on the falling rat period in which the rate of evaporation tends to fall as the moisture content decreases and the drying curve decays exponentially towards the equilibrium moisture content. Rapid moisture removal from seeds was obvious in all experiments particularity at higher heating surface temperature and longer exposure time. The result also showed that both the simple and the modified exponential equation models were satisfactorily described the drying behavior of canola seeds and predicted the change in seeds moisture contents indicated by lower values of standard error of estimate (SE) and the higher coefficient of determination(R2).Meanwhile, high temperature conduction heating the extracted canola oil was stabilized as reeducated from the lower values of free fatty acids of the samples stored under room temperature. In general, it can be said that, the accelerated drying and heat stabilization of canola seeds using the conduction heating rotary dryer may be considered as an effective procedure for moisture, and oil stabilization.

\section{INTRODUCTION}

T $\mathrm{t}$ is a low-glucosinolate low-erucic acid (LEA) rapeseed. LEA rapeseeds are grown in canade Europe and Australia. Canola and LEA rapeseed contain on average $44-48 \%$ oil on a dry basis depending on the growing area and conditions. The fatty acid composition of the oil makes it a healthy crop with a high level of monounsaturated fatty acids (> 55\%) and an excellent omega-6/omega-3 ratio (2/1).

1) Professor of Agricultural Engineering, Faculty of Agriculture, Menoufia University.

2) Assistant Professor of Agricultural Engineering, Faculty of Agriculture, Menoufia University.

3) Head of Research and Director of the Institute of Agricultural Engineering Research Dokki - Giza.

4) Research assistant at the Agricultural Engineering Research Institute. 
Canola oil is mainly used for food; however, it could also be used to produce biodiesel. Canola is a member of the mustard (Brassicaceae) family. Canola (Brassica napus) was originally developed in Canada through traditional breeding of the rapeseed plant. Production of vegetable oil is the main use of the seed, with the leftover meal used as a protein supplement for livestock (Boyles et al., 2012).

Canola oil is used for the production of consumables such as margarine, shortenings and salad oil, Both canola and rapeseed oil are also used in the production of inedible products such as cosmetics, industrial lubricants, fungicides, herbicides, pesticides, plasticisers, suntan oil, and in the anti-static substance for paper and plastic wrap, The Canadian livestock feed industry is also an important market for Manitoban crushers as canola meal is used in dairy, beef, swine and poultry rations (A.F.P 2008).

Canola seeds (rapeseeds with low erucic acid and glucosinolate contents) contain high amounts of oil proteins (36-44\%) (Xu and Diosady, 2012). According to the Foreign Agricultural Service (2016), canola (including edible rapeseed) is the second largest global oilseed crop after soybeans, with production of 70.2 million metric tons in 2015/16. North Dakota dominates production in the U.S. with $87 \%$ of the canola crop in 2015. But canola acreage has also been growing in the southern United States. For example, Oklahoma has been the number two producer of canola in the U.S. since 2009 (USDA, 2015).

Hamed (2015) conducted on experimental work to study and simulate high-temperature short time drying behavior of peanuts pods under the high temperature drying process using a laboratory scale rotary dryer. The experimental work was conducted at six different levels of heating surface temperature $\left(55,65,75.85,95\right.$ and105 $\left.c^{0}\right)$ three levels of cylinder rotational speed (3,6 and 9 r.p.m) and three peanuts batch mass (1,1.5 and $2 \mathrm{Kg} / \mathrm{batch})$ the high temperature rotary drier was evaluated in terms of operation factors are moisture regime, drying temperature ,pods and kernels temperatures ,batch mass feed, rotational speed and compatibility of experimental data to Lewis and Henderson and Pabis's model. The heating surface temperature of $65 \mathrm{c}^{0}$,cylinder rotational speed of 6 r.p.m and pods batch mass of $1.5 \mathrm{~kg} / \mathrm{batch}$ per time recorded the lowest values 
of kernels splitting ,broken and shriveling percentages .However considering the shorter drying time, and the lower fungal colony count of both temperature levels ,the heating surface temperature of $65 \mathrm{C}^{0}$ is recommended. The mathematical analysis showed that, both studied models could satisfactorily describe the drying behavior of high moisture peanuts pods .However, the Lewis's model could be considered more proper for describing the drying behavior and predicting the changes in pods moisture content during the drying process due to more simplicity of this model in calculation and mathematic analyses.

\section{MATERIALS AND METHODS}

\section{The accelerated rotary dryer (conduction heating):}

The accelerated drying unit (figures 1) was fabricated at the workshop of Rice Mechanization Center, Agric. Eng. Res. Institute, Kafr El-Sheikh Governorate. The unit consists of a rotary cylinder with dimension (0.6 $\mathrm{m}$ in diameter and a $0.2 \mathrm{~m}$ long) made of I mm thinness galvanized iron steel sheet enclosed by a fixed insulated cylinder $(0.8 \mathrm{~m}$ in diameter and $0.3 \mathrm{~m}$ long. One side of the rotary cylinder connected to a driving mechanism consists of $0.15 \mathrm{~m}$ diameter steel flange fixed to the side cover of the rotary cylinder and welded to a steel bar riding into a heavy duty ball bearing. A $0.5 \mathrm{~kW} / \mathrm{h}$ low speed motor with different sizes of pulleys used for power supply and speed control of the rotary cylinder. The other side of the rotary cylinder serves as an inlet for canola seeds samples through a $0.1 \mathrm{~m}$ diameter center hole. The heat treated canola seeds discharged through a perforated removable sector of the cylinder bottom. For heating and temperature control of the rotary cylinder surface, two $\mathrm{kW}$ electric resistance heaters were placed at the inner surface of the fixed insulated cylinder (between the rotary cylinder and the insulated exterior cylinder) to heat the surface of the rotary cylinder (figure 1).

\section{Test Crop:}

Freshly harvested canola seeds (seror 4) were used for the experimental work. The harvesting and threshing operations of canola pods were executed manually at initial moisture content of $(21 \%, 27 \%$ and $31 \%)$ (d.b). Unfilled seeds and other impurities were discarded from the harvested seeds. The canola seeds were sealed in separate polyethylene 
bags. The bags were stored in a freezer adjusted at temperature of $-5 \pm$ $1 \mathrm{oC}$ to prevent moisture loss and fungal growth throughout the storage period. Before each test, the required quantities of seeds were taken out from the freezer and allowed to reach the normal room temperature. The moisture content of the samples was measured just before each test.

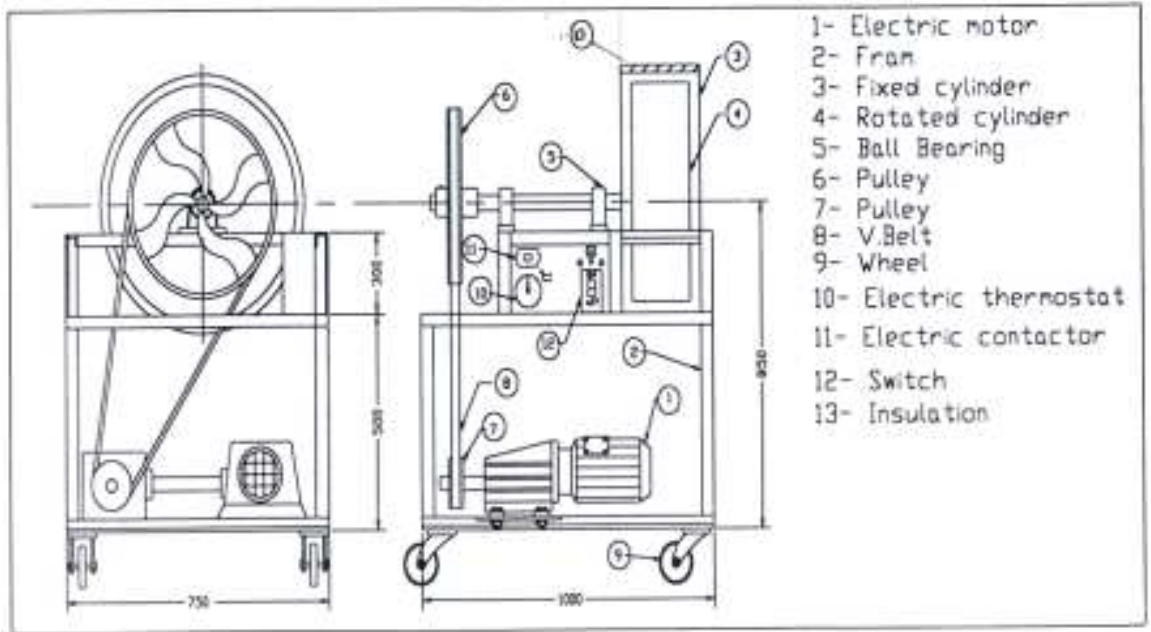

Figure (1): Schematic diagram of the accelerated drying unit.

\section{Experimental procedures:}

High temperature short time drying technique (HTST) for canola seeds was applied under three different levels of initial moisture content $(21 \%, 27 \%$ and $31 \%$ w.d) seven different levels of heating surface temperatures $(85,95,105,115,125,135$ and $145 \mathrm{o}$ C) and six different levels of exposure time $(3,6,9,12,15$ and $18 \mathrm{~min}$.

\section{Test procedure and Test procedure:}

Before each experimental run, seeds samples were taken out from the freezer and left until the initial temperature of seeds approached a level equal to that of room temperature. The samples were kept at insulated container in order to maintain the uniformity of the initial seeds temperature during the experimental work. Prior to each experiment, a dummy sample was used and the temperature of the cylinder surface was adjusted at the required level. When the surface temperature of the rotary cylinder becomes stable the dummy sample discharged and replaced by the testing sample. 
Drying runs started after the required heating surface temperature of the drying unit was attained. After heating the seeds ( $2 \mathrm{~kg} / \mathrm{run})$ to the required heating time, they were cooled to room temperature in wooden box covered with a perforated aluminum foil to allow gradual escape of vapor during the cooling process. After cooling process, the heat treated seeds were taken out from the cooling wooden box, and then divided into two sub samples, the first one used to determine seeds final moisture content, while the second one was used for oil extraction and determination of Free Fatty Acid (FFA \%) and Peroxide value.

\section{Experimental Measurements and Instrumentation: Surface temperature of the rotary cylinder:}

The remote-type infra-red spot thermometer model (HT-11) was used to measure the rotary cylinder surface temperature of the stabilization heating unit during the rotation process. The emissive of the thermometer was adjusted at 0.85 for iron sheet surfaces and the temperature was measured at different points. The heating surface temperature was considered as the average of the obtained readings.

\section{Moisture content of canola seeds:}

The standard A.O.A.C (1991) moisture measuring method used for determining the seeds moisture content after each drying run. Five grams of canola seeds were placed at $135 \mathrm{oc}$ for $3 \mathrm{~h}$, and then kept in a desiccators at room temperature .The dried samples were weighed again using an electronic digital balance and the moisture content of bran was calculated on dry basis.

\section{Bulk temperature of the heat-treated canola seeds:}

The bulk temperature of canola seeds was immediately measured at the end of each experimental run .The discharged seeds were received in an insulated iron cylinder and the sensing prop of a one point temperature meter model (A.W. SPERRY DM -8600, Taiwan) with range of 0 to $400 \mathrm{c} 0$ was inserted through the seed bulk until reaching a constant reading.

Free fatty acids (FFA\%) in the extracted canola oil:

Oil samples were extracted from canola seeds by soaking the crushed samples at petroleum solvent for 24/48hrs under room temperature. the 
solvent was completely re/gained by evaporation using a heated water bath at $850 \mathrm{c}$ and condensing it unit the remained oil samples were filled in glass bottles and used for the required measuring tests. The FFA \% of oil samples were calculated as oleic acid using the corresponding acid value of each samples according to the A.O.A.C.(1991)as follows:

$$
F F A \%=\frac{A . \mathrm{V}}{1.99}
$$

Where:

\section{A.V : Acid value}

The values 282 and 56.1 refer to the equivalent weight of oleic acid and the potassium hydroxide $(\mathrm{KOH})$ respectively. It should be mentioned that, to get true results of the free fatty acids, the laboratory tests were conducted after 15 days of samples storage under room condition.

\section{Theoretical mathematical applied the drying process:}

The simple drying equation Lewis's (1921) Henderson and Pabis's (1961) and the modified simple drying equations were examined for describing the drying behavior and predicting the change in canola seeds moisture content under the accelerated drying method. The simple drying equation written as follows.

$$
M R=\frac{M-M_{e}}{M_{o}-M_{e}}=\exp \left(-k_{s} t\right)
$$

Where:

MR : Moisture ratio, dimensionless.

M : Instantaneous seeds moisture content at time t, (\%,w.b).

Me : Equilibrium moisture content. (\%, w.b).

Mo : Initial moisture content, \% (w.b).

$\mathrm{t} \quad$ : Time, $\min$

ks : Drying constant, min -1

There is no information available about the equilibrium moisture content of canola seeds in a temperature range of 95 to $145 \mathrm{oC}$ when the air relative humidity is very low, However the canola seeds will be bone dried after prolonged heating under such condition. So the moisture ratio was approximated simply by dropping the equilibrium moisture content 
term and thus the ratio of instantaneous seeds moisture content of sun flower seeds to its initial moisture content was used for representing seeds moisture ratio.

\section{The drying constant $(\mathrm{kS})$ of the simple drying:}

The simple exponential model has been converted to the following from:

$$
M R=\frac{M_{1}}{M_{o}}=\exp \left(-k_{s} t\right)
$$

While, The modified Simple Exponential model was Converted to the following form:

$$
M R=\frac{M_{l}}{M_{o}}=A \exp \left(-k_{h} t\right)
$$

While, The drying constant (kh \&A) of the modified simple drying models were obtained by applying linear regression analysis to the logarithmic value of $(\mathrm{M} / \mathrm{Mo})$ and the drying time $(\mathrm{t})$. The slope of the best fit straight line represents the value of the drying constant $(\mathrm{ks})$. were obtained by applying linear regression analysis of the value $\log (\mathrm{M} / \mathrm{Mo})$ and the drying time ( $\mathrm{t}$ ). The slope of the best fit straight line represent the drying constant $(\mathrm{kh})$ and the intercept represents the Constant(A).

\section{RESULTS AND DISCUSSION}

Figures (2): (4) present the change in seeds bulk temperature as related to exposure time at different levels of heating surface temperature. The results show that, seeds bulk temperature increased with the increase of exposure time and heating surface temperature.

\section{Seeds Moisture Content:}

Figures (5), illustrated the change in seeds moisture content as related to exposure time at different levels of cylinder surface temperatures. The results presented showed that rapid moisture removal from seeds was obvious in all experiments particularly at higher heating surface temperature and longer exposure duration. Meanwhile, all the drying processes occurred at the falling rate period in which the rate of evaporation tends to fall as the moisture content decreases and the drying curve decays exponentially towards the final moisture content. 

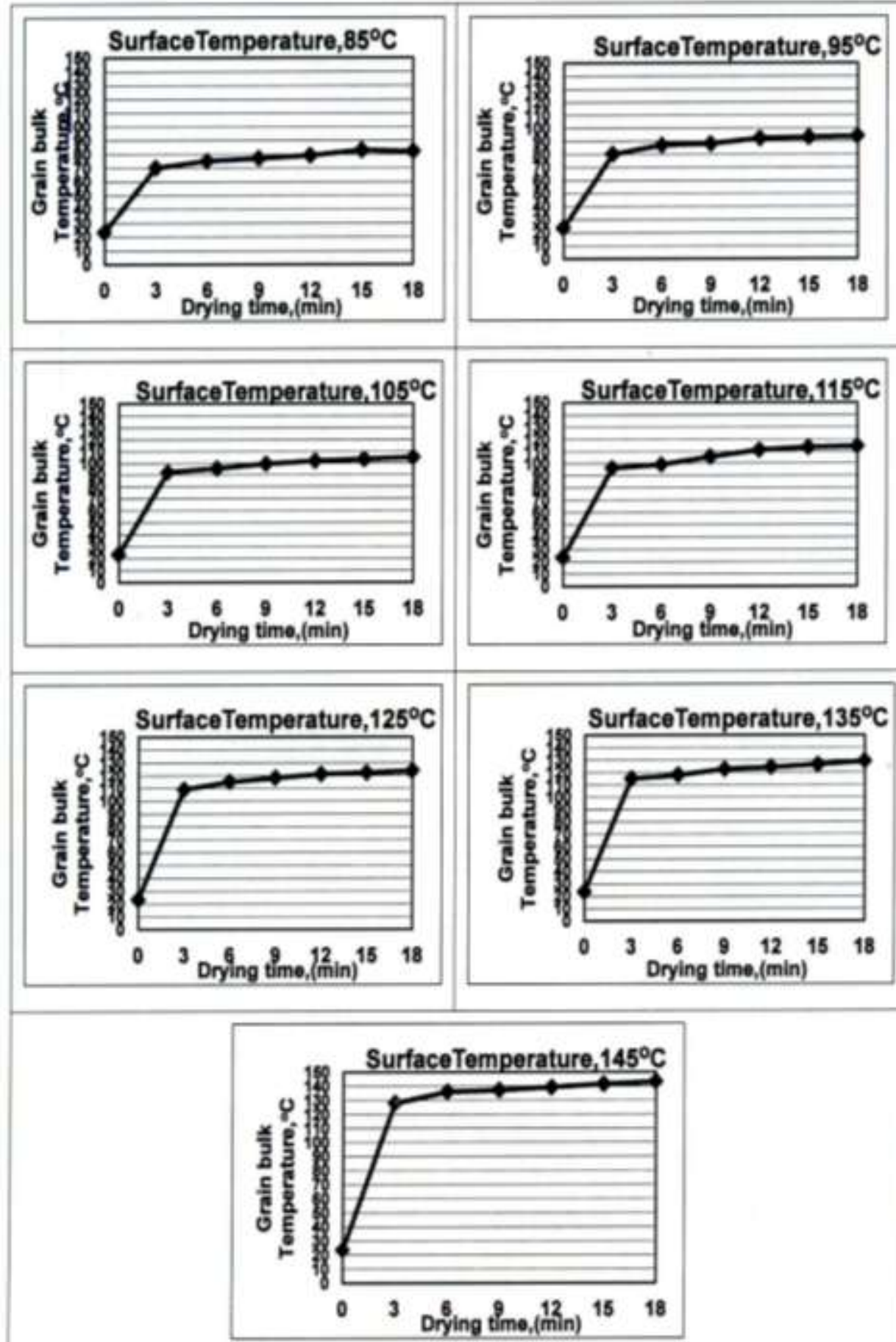

Fig(2): Change in Canola seeds bulk temperature 


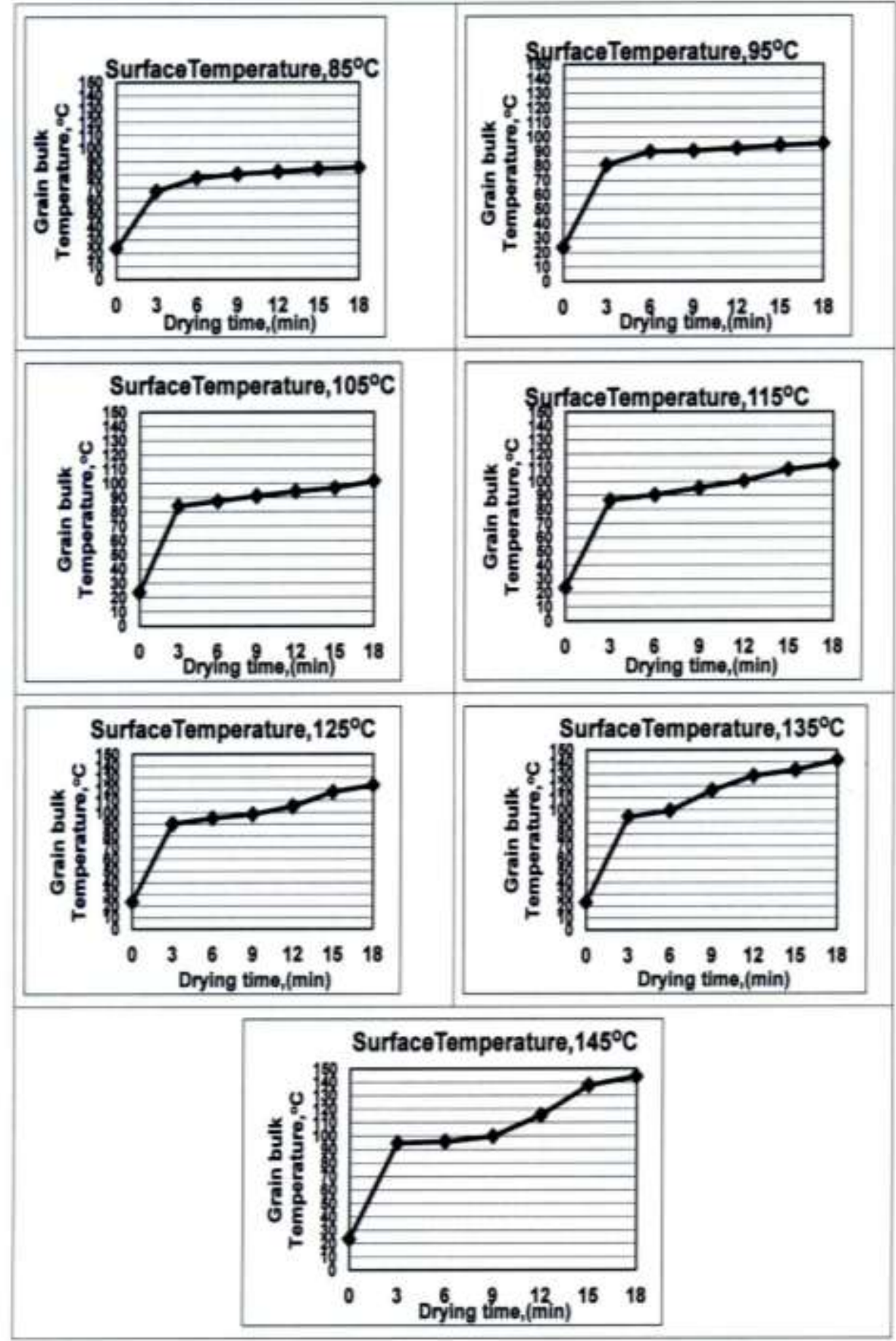

Fig. (3): Canola seeds bulk temperature under different cylinder surface temperature at $\mathrm{MC}=27 \%(\mathrm{db})$. 


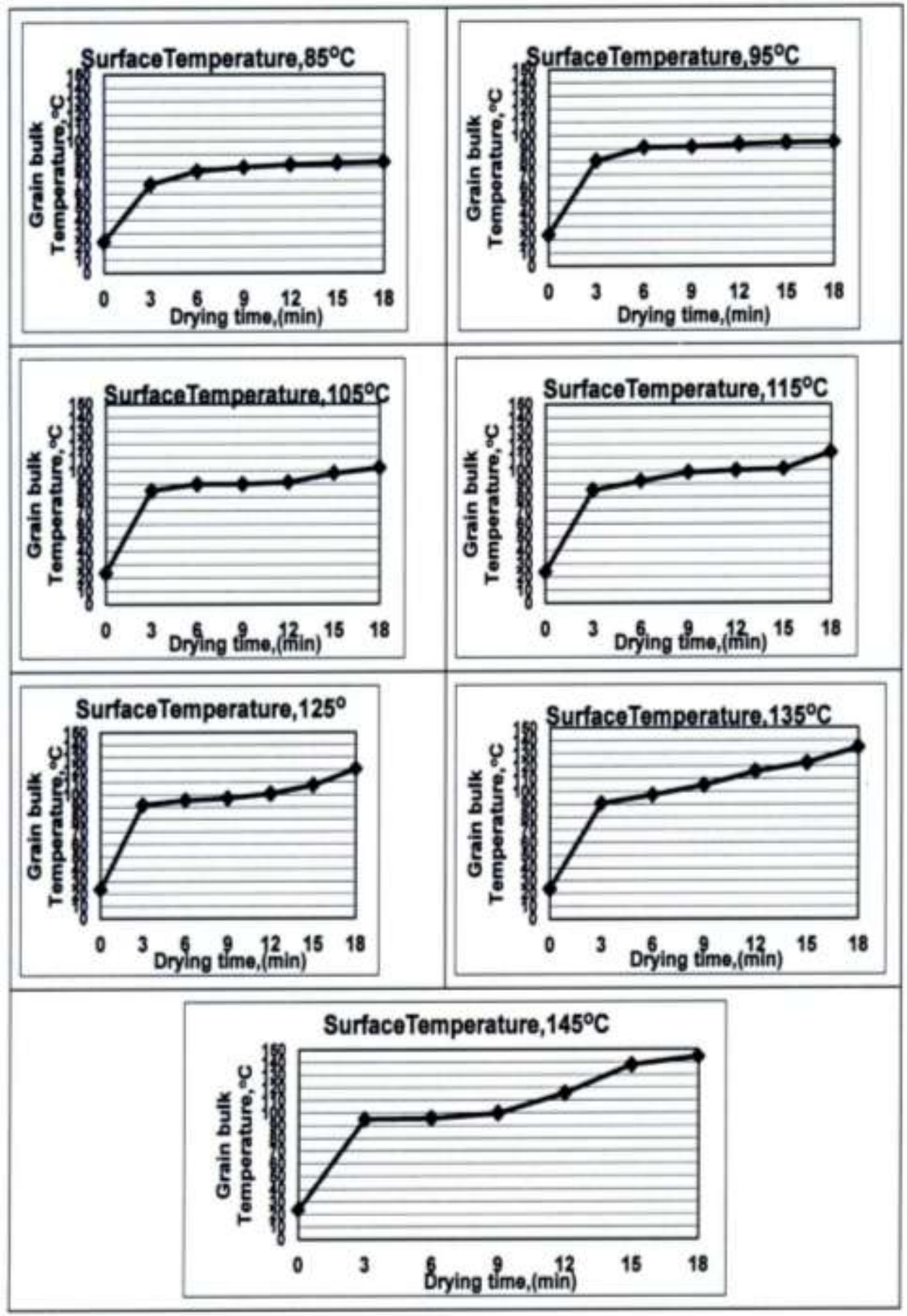

Fig. (4): Canola seeds bulk temperature for different cylinder surface temperature at $\mathrm{MC}=31 \%$ (db.). (Ts : Surface Temperature) 

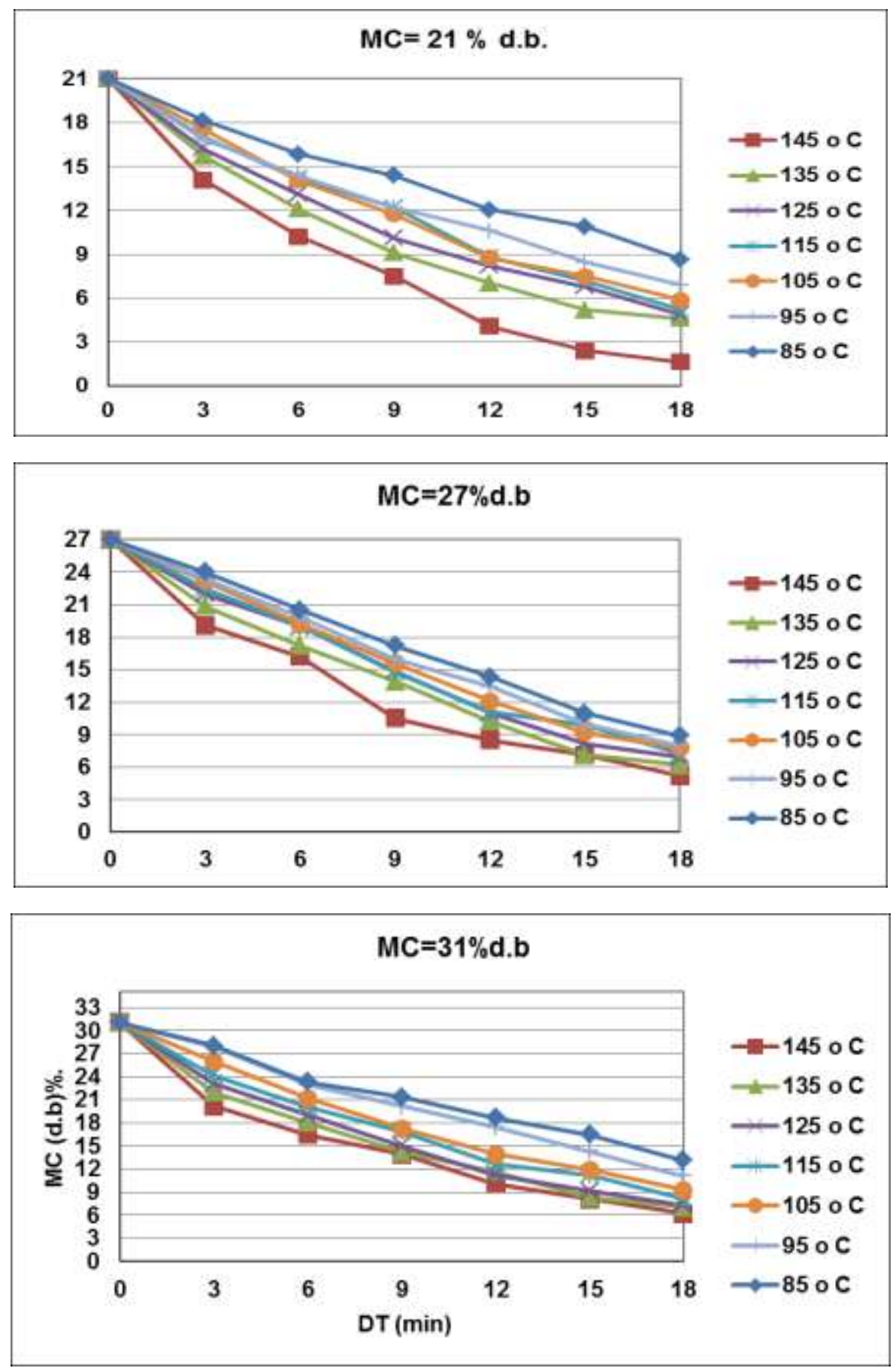

Fig (5): Drying curve for canola seeds under different cylinder surface temperatures. 
Analysis of drying curves:

Simple Drying Model:

Table (1): Constant $\left(k_{L}\right)$ for Lewis model .

\begin{tabular}{|c|c|c|c|}
\hline \multirow{2}{*}{$\begin{array}{c}\text { Temperature } \\
\left({ }^{\mathrm{O}} \mathrm{C}\right)\end{array}$} & \multicolumn{3}{|c|}{$\mathrm{K}_{\mathrm{L}}$} \\
\cline { 2 - 4 } & $\mathbf{3 C} \%$ & $\mathbf{2 1} \%$ \\
\hline $\mathbf{8 5}$ & $\mathbf{0 . 0 4 6}$ & $\mathbf{0 . 0 5 7}$ & $\mathbf{3 1} \%$ \\
\hline $\mathbf{9 5}$ & $\mathbf{0 . 0 6 0}$ & $\mathbf{0 . 0 6 3}$ & $\mathbf{0 . 0 5 2}$ \\
\hline $\mathbf{1 0 5}$ & $\mathbf{0 . 0 6 9}$ & $\mathbf{0 . 0 6 7}$ & $\mathbf{0 . 0 6 5}$ \\
\hline 115 & $\mathbf{0 . 0 7 2}$ & $\mathbf{0 . 0 7 0}$ & $\mathbf{0 . 0 7 1}$ \\
\hline 125 & $\mathbf{0 . 0 7 8}$ & $\mathbf{0 . 0 7 4}$ & $\mathbf{0 . 0 8 1}$ \\
\hline 135 & $\mathbf{0 . 0 8 9}$ & $\mathbf{0 . 0 8 2}$ & $\mathbf{0 . 0 8 4}$ \\
\hline 145 & $\mathbf{0 . 1 3 7}$ & $\mathbf{0 . 0 9 3}$ & $\mathbf{0 . 0 9 1}$ \\
\hline
\end{tabular}

Calculation of the drying constants $\left(\mathrm{K}_{\mathrm{H}}\right)$ and (A) for Henderson and pabis's model:

Table (2): Drying Constant $\left(k_{H}\right)$ of Lewis model .

\begin{tabular}{|c|c|c|c|}
\hline \multirow{3}{*}{$\begin{array}{c}\text { Temperature } \\
\left({ }^{\circ} \mathbf{C}\right)\end{array}$} & \multicolumn{3}{|c|}{$\mathbf{k}_{\mathbf{H}}$} \\
\cline { 2 - 4 } & $\mathbf{3 C} \%$ & $\mathbf{2 7} \%$ & $\mathbf{3 1} \%$ \\
\hline $\mathbf{8 5}$ & $\mathbf{0 . 0 4 7}$ & $\mathbf{0 . 0 6 2}$ & $\mathbf{0 . 0 4 6}$ \\
\hline $\mathbf{9 5}$ & $\mathbf{0 . 0 5 9}$ & $\mathbf{0 . 0 6 8}$ & $\mathbf{0 . 0 5 5}$ \\
\hline 105 & $\mathbf{0 . 0 7 1}$ & $\mathbf{0 . 0 7 1}$ & $\mathbf{0 . 0 6 6}$ \\
\hline 115 & $\mathbf{0 . 0 7 6}$ & $\mathbf{0 . 0 7 3}$ & $\mathbf{0 . 0 7 1}$ \\
\hline 125 & $\mathbf{0 . 0 7 8}$ & $\mathbf{0 . 0 7 8}$ & $\mathbf{0 . 0 8 0}$ \\
\hline 135 & $\mathbf{0 . 0 8 7}$ & $\mathbf{0 . 0 8 4}$ & $\mathbf{0 . 0 8 1}$ \\
\hline 145 & $\mathbf{0 . 1 4 4}$ & $\mathbf{0 . 0 9 0}$ & $\mathbf{0 . 0 8 5}$ \\
\hline
\end{tabular}

Table (3): The calculated drying constant (A) of Henderson and Pubis's model.

\begin{tabular}{|c|c|c|c|}
\hline \multirow{2}{*}{$\begin{array}{c}\text { Temperature } \\
\left({ }^{\circ} \mathrm{C}\right)\end{array}$} & \multicolumn{3}{|c|}{$\mathbf{A}$} \\
\cline { 2 - 4 } & $21 \%$ & $27 \%$ & $31 \%$ \\
\hline 85 & 0.009 & 0.065 & 0.019 \\
\hline 95 & 0.009 & 0.060 & 0.043 \\
\hline 105 & 0.023 & 0.052 & 0.013 \\
\hline 115 & 0.044 & 0.037 & 0.005 \\
\hline 125 & 0.008 & 0.050 & 0.021 \\
\hline 135 & 0.029 & 0.024 & 0.046 \\
\hline 145 & 0.018 & 0.038 & 0.028 \\
\hline
\end{tabular}


As shown in table (4-5) the drying constant (A) showed values ranged from 0.005 to 0.065 . Also, the regression analysis showed no direct relationship between the constant (A) and the experimental variables. So, the drying constant (A) was taken as (0.0361) which represents the mean values of the calculated data in table (3).

\section{Free Fatty Acids (FFA \%) in the extracted oil:}

The presence of lipase enzyme in canola oil hydrolyses it to free fatty acids and glycerol. Also oxidation of free fatty acids leads to produce various off odor compounds such as aldehydes and ketones. The free fatty acids tests were conducted only for the samples which approached the safe storage moisture content of canola seeds in the range of $(5-7 \% \mathrm{db}$.).

Table (4) illustrates the change in percent of free fatty acids in relation to heating surface temperature and exposure time. The result show that the free fatty acid percent of the control sample (sun dried seeds to a moisture content of about $6.85 \% \mathrm{db}$.) approached a level of $17.56 \%$ and, The percentage of oil content (32\%), it is a high toxic percent to the human consumption as the permitted level for FFA $\%$ in canola oil is up to $2 \%$, while it was ranged from 1.75 to $3.61 \%$ for the heat treated samples.

Table (4): Free Fatty Acids (FFA \%) and Percentage of oil and other related parameters in the extracted oil.

\begin{tabular}{|c|c|c|c|c|c|c|}
\hline $\begin{array}{c}\text { Moisture } \\
\begin{array}{c}\text { Content } \\
\text { in, \% }\end{array}\end{array}$ & $\begin{array}{c}\text { Moisture } \\
\text { Content } \\
\text { out, \% }\end{array}$ & $\begin{array}{c}\text { Drying } \\
\text { time } \\
\text { min. }\end{array}$ & $\begin{array}{c}\text { Heating } \\
\text { Surface } \\
\text { Temp., } \\
\text { C }\end{array}$ & $\begin{array}{c}\text { Seeds } \\
\text { bulk } \\
\text { Temp., } \\
\text { C }\end{array}$ & $\begin{array}{c}\text { Oil, } \\
\%\end{array}$ & $\begin{array}{c}\text { F.F.A. } \\
\%\end{array}$ \\
\hline \multirow{5}{*}{21} & 6.9 & 18 & 95 & 94.4 & 44 & 1.90 \\
\cline { 2 - 8 } & 5.86 & 18 & 105 & 101.9 & 41 & 1.88 \\
\cline { 2 - 8 } & 5.9 & 18 & 115 & 113.7 & 42 & 1.75 \\
\cline { 2 - 8 } & 6.8 & 15 & 125 & 107.8 & 39 & 1.93 \\
\cline { 2 - 8 } & 4.9 & 18 & 125 & 120.2 & 40 & 1.83 \\
\hline \multirow{3}{*}{27} & 5.2 & 15 & 135 & 121.9 & 39.5 & 1.82 \\
\cline { 2 - 8 } & 6.9 & 18 & 125 & 123.1 & 40.5 & 1.87 \\
\cline { 2 - 8 } & 6.2 & 18 & 135 & 134 & 39 & 2.91 \\
\hline 31 & 5.2 & 18 & 145 & 144.1 & 40.2 & 1.89 \\
\hline
\end{tabular}


The observed increase in the percentage of free fatty acid in the control sample may come from the activity of lipase enzyme which causes a breakdown of triglyceride into it's components.

In general, it can be said that the heating surface temperature of $115^{\circ} \mathrm{C}$ and the exposure time of 18 minute decreased the moisture content of canola seeds to the safe level of 5.9\%d.b., and percentage of free fatty acid 1.75 .

It can described the drying behavior of canola seeds as indicated by high values of coefficient determination $\left(\mathrm{R}^{2}\right)$ and low values of standard error (SE) as presented in table (A-21) show the observed and calculated values of moisture content for the minimum and maximum levels of drying temperature.

Table (5): The over average of the obtained $\left(\mathrm{R}^{2}\right)$ AND (SE) for all studied drying model.

\begin{tabular}{|c|c|c|}
\hline Model & $\mathrm{R}^{2}$ & $\mathrm{SE}$ \\
\hline Lewis & 0.982185 & 0.987346 \\
\hline Henderson & 0.986605 & 0.98235233 \\
\hline
\end{tabular}

The results show that, the two models could describe the drying behavior of canola seeds as indicated that the value of coefficient of determination $\left(\mathrm{R}^{2}\right)$ in Henderson's model is higher than in Lewis's model, while Lewis's model is higher than Henderson's model in standard error (SE). So the best model is Henderson's model.

Table (6): values of coefficient of determination (r), chi $-\operatorname{square}\left(\mathbf{x}^{2}\right)$, mean bias error (MBE) and root mean square error (RMSE) to Lewis and Henderson pubis's model.

\begin{tabular}{|c|c|c|c|c|c|c|c|c|c|}
\hline $\mathrm{T}$ & $\mathrm{MC}$ & \multicolumn{3}{|c|}{ Lewis's model } & \multicolumn{5}{c|}{ Henderson's model } \\
\hline & & $\mathrm{X}^{2}$ & $\mathrm{RMSE}$ & $\mathrm{MBE}$ & $\mathrm{R}$ & $\mathrm{X}^{2}$ & $\mathrm{RMSE}$ & $\mathrm{MBE}$ & $\mathrm{R}$ \\
\hline & & & & & & & & & \\
\hline
\end{tabular}

\section{CONCLUSION}

From the obtained data ,it can be concluded that the accelerated drying and heat stabilization of canola seeds using the conduction heating rotary dryer may be considered as an effective procedure for moisture reduction ,and oil stabilization. 
The heating surface temperature of $115^{\circ} \mathrm{C}$ and the exposure time of 18 minute decreased the moisture content of canola seeds to the safe level of $5.9 \%$ w.b., and percentage of free fatty acid 1.75 .

\section{REFERENCES}

Agriculture and Food Processing (2008): Commodities Grains \& Oilseeds(https://www.gov.mb.ca/trade/globaltrade/agrifood/commo dity/canola.html(1/12/2017).

A.O.A.C. (19991): Association of official agriculture chemists. Official methods of analysis of $15^{\text {th }} \mathrm{ed}$, D.C (USA)

Boyles, M.; Bushong, J.; Sanders, H. and Stamm, M. (2012): Great Plains Canola Production Handbook Revised. MF2734

Hamad, T.O.I (2015): Some engineering factors affecting drying and storage of peanut crop. Un-published M.Sc. Thesis Dep. of Agric. Eng. Fac. of Agric. Al-Azhar Univ.

USAD (2015): Crop production annual summary. Retrieved 7/4/2015, fromhttp://usda.mannlib.cornell.edu/MannUsda/viewDocumentInfo. do?document $\mathrm{ID}=1047$.

Xu, L. and Diosady, L.L. (2012): Processing of canola proteins: a review U. Thiyam-Hollaender, N.A.M. Eskin, B. Matthäus (Eds.), Canola and Rapeseed: Production, Processing, Food Quality and Nutrition. CRC Press, Boca Raton (2012), pp. 59-78.

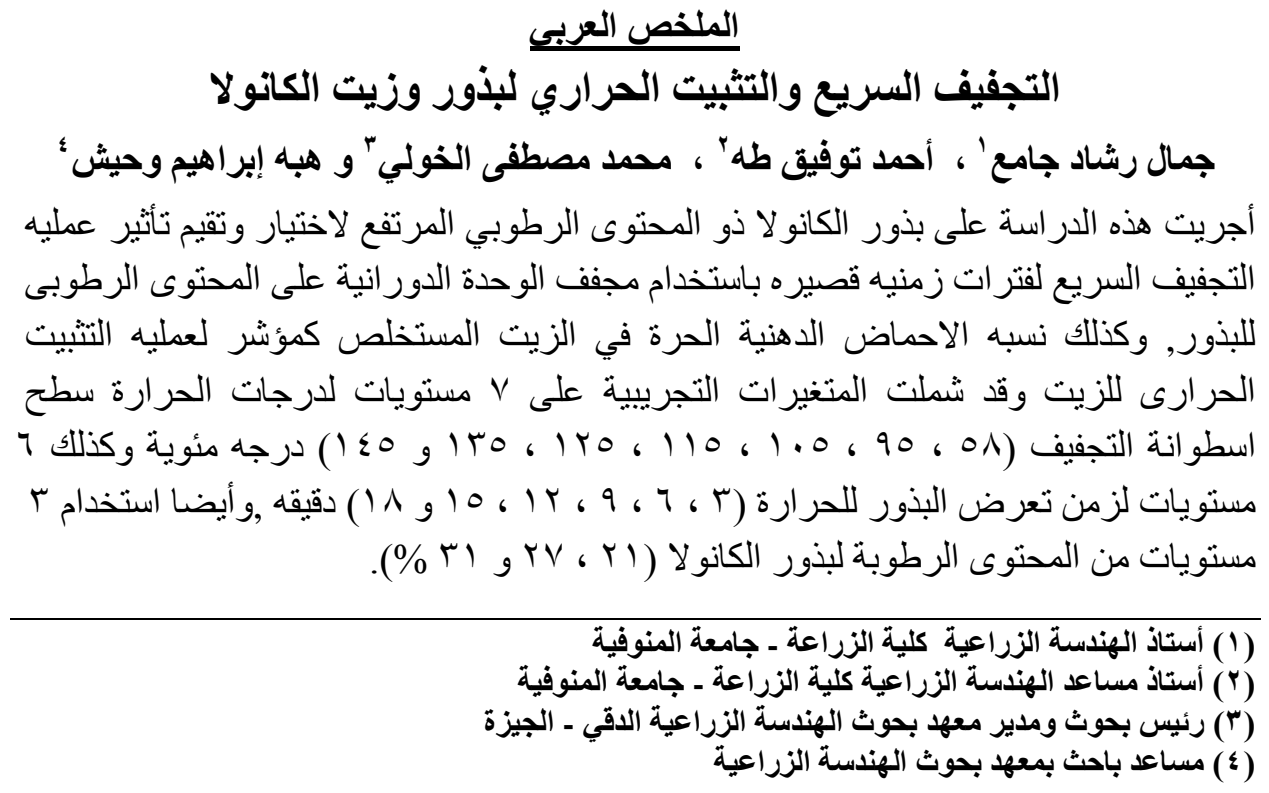




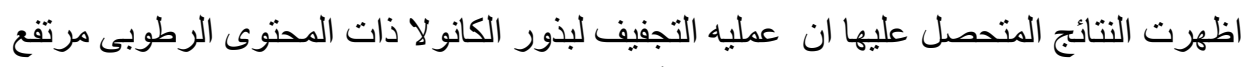

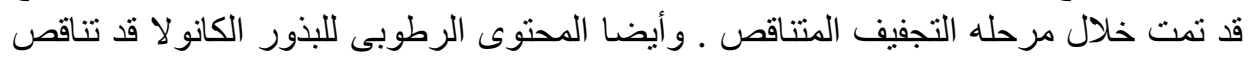

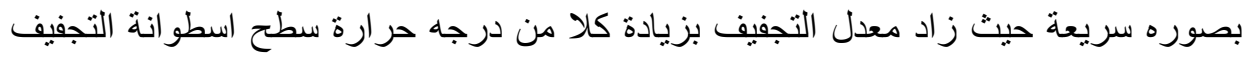

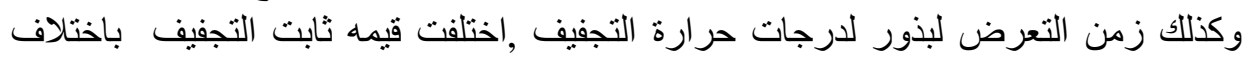

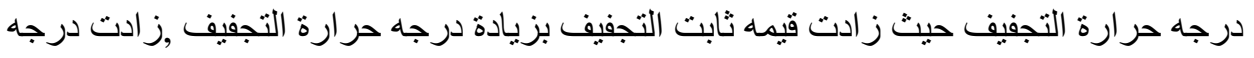

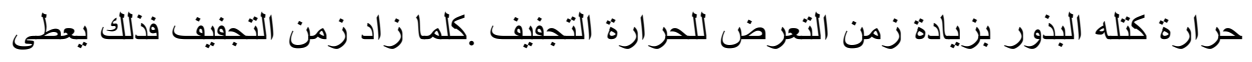

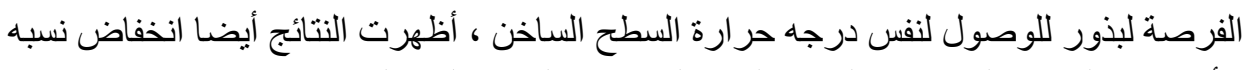

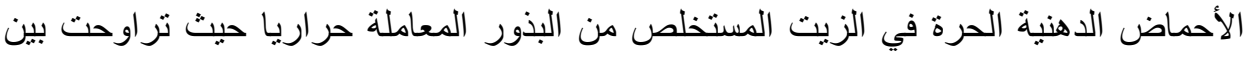

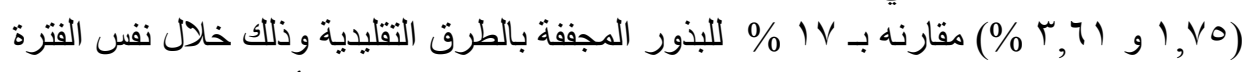

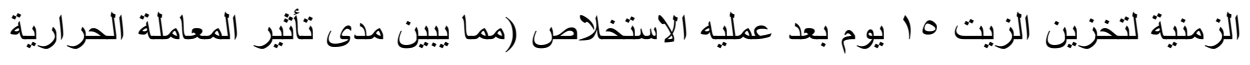

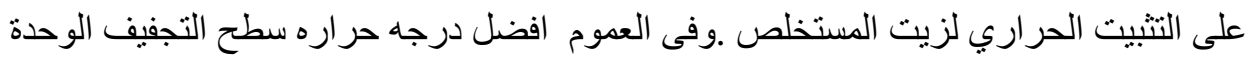

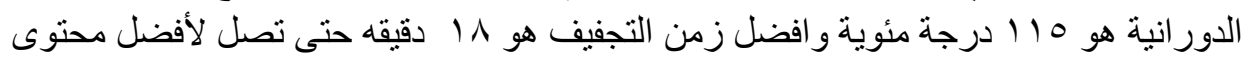

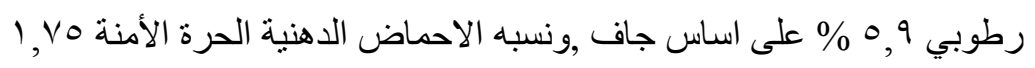

